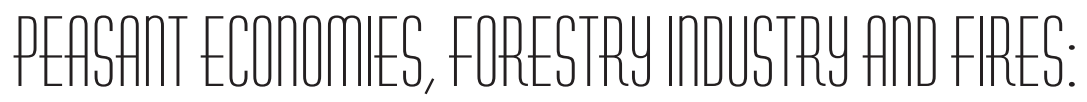

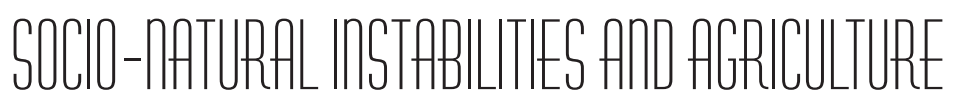 AS MEAARS OF RESISTANCE
}

BEATRIZ EUGENIA CID AGUAYO ${ }^{2}$

\section{Introduction}

At the beginning of 2012, widespread fires dramatically devastated the center of industrial forestry production in Chile, consuming not only extensive forestry plantations and cellulose factories, but also adjacent agricultural lands. This tragedy represented a strategic opportunity to problematize the relationship between forestry industry -arrived over the past few decades- and preexistent peasant agriculture and the process of coproduction of nature that has been developed in the region.

On December 31st, 2011, several fire spots dispersed at the center of forestry plantations in the Biobío and Araucanía Regions and spread rapidly after unusually high temperatures and winds. After only a day, more than 8,000 hectares $(19,800$ acres) were consumed and the fire was under control only by January $6^{\text {th }}$, after clearing 28,000 hectares (70,000 acres) of forestry plantations, forests and agricultural crops in the Biobío Region. Hundreds of families lost their houses, storehouses, work tools and crops. The fire had a considerable impact on the media, because of the overwhelming losses (a megathrust earthquake devastated the same area on February 2010), the death of seven forest firefighters and the possible relation with the Mapuche conflict.

Under these circumstances, different types of practical solidarity -material help to the victims- and afterwards strategic political solidarity arose. In particular, the leaders of the National Association of Rural and Indigenous Women (ANAMURI) -a national organization member of Vía Campesina- requested the support of female professors of the Universidad de Concepción to carry out an assessment of fire damages to peasant economies. In this context, a number of internship students of the departments of Sociology and Geography of the Universidad de Concepción gathered data in the Municipalities of Quillón, Florida and Ranquil (Biobío Region) assessing the damage with interviews

1. This article was supported by FONDECYT under the grant: "Agroecología y Agricultura Orgánica en el Centro Sur de Chile: . Cadenas de Valor y Redes de Gobernanza" (№ 11110020)

2. Sociologist (P.U.C. Chile), MSc in Sociology (Universidad de Chile), PhD in Sociology (York University). Associated Professor, Faculty of Social Science, Universidad de Concepción. E-mail: beatrizcid@udec.cl 
to neighborhood leaders and participatory mapping. These data revealed the dramatic impacts of fires on families and peasant economies. These results were informed to peasant organizations during the political event "Semillas Campesinas de Solidaridad" (Peasant Seeds of Solidarity) on April 2012. Later, after academic consideration, a political and strategic objective was set in order to problematize the socio-natural relationships between the forestry accumulation model and peasant economies. This revealed the characteristics of an extractive accumulation model and a predatory environment, which has transformed economies and the rural landscape into a conflicting neoliberal nature for human and non-human inhabitants.

This article begins by reviewing the history of peasant agriculture and the forestry industry; further, the relationships between nature and society are discussed. We present important data gathered during the assessment as a mean to problematize the articulations and disarticulations of forestry production and peasant economies. Finally, this article ends with a reflection on the roles of peasant political actors in this context.

\section{Peasant Agriculture in Center-South Chile: between a frustrated peasantization and regions of refuge.}

In Chile, the formation of an economically independent peasant class has been a historically frustrated project. From the beginning of the Republic, rural territories were hegemonized by haciendas (farms), oriented principally to the exports of wheat -to Lima and California- and including permanent and "itinerant" workers. Only in the borders of these territories, small farms and low-scale commercial lands were oriented to production for the internal market (Bengoa, 1988). The exporting economies of haciendas were also continuously neutralized by commercial capital (Salazar, 2003). During the 1960's to early 1970's, the agrarian reform -developmentalist approach- attempted to modernize agriculture and to develop an independent peasant class - of direct producers- (Chonchol, 2006). However, the package of economic and political reforms implemented during the military dictatorship -and consolidated during succeeding democratic governments- undermined this effort and established a neoliberal agro-exporting model in Chile, hegemonized by the agri-food industry weakening the political and economic position of peasant groups.

Immediately after the coup d'état of 1973, the agrarian reform process was blocked. Although only a third of the reformed lands was returned to the previous owners, the general result was a liberation of the land market and, later, a re-concentration process. The remaining two thirds of land were tendered or recognized to the beneficiary peasants of the reform. The first case resulted in a net transfer of lands to a growing entrepreneurial elite, which made a more intensive and agro-commercial use of land (Gómez and Echenique, 1988). In the second case, the lands were transformed in small private plots -with low productive viability-, and were largely acquired by agricultural, forestry and real estate entrepreneurs in the late 1970's (Echenique and Rolando, 1991).

During the 1980's, agribusinesses experienced an important growth, reaching an important position in the world market, especially in the niches of fresh products, premium wine and Atlantic salmon. This development was stimulated by: (1) the low cost of 
land during the agrarian counter-reform; (2) the State support to research and development of the agri-food sector to improve comparative advantages, such as Mediterranean counter-season and low recurrence of plagues; (3) a labor market established during the dictatorship and repression, which facilitated labor flexibility and undermined unionization initiatives; (4) an open and deregulated climate to the entrance of international capital.

The combination of these factors resulted in an extraordinary expansion of food exports. This process was led by corporations whose operations were characterized by monoculture, agrochemicals abuse, temporary employment and exclusion of peasants and farmers. With the return to democracy, this model suffered little modification (Gwynne and Kay, 1997; Kay, 2002), under the slogan: "Chile Potencia Agroalimentaria" (Chile Agri-food Power).

The Biobío Region followed these dynamics, reaching a considerable development of the forestry and paper industrial complex, whose expansion was intensified by the same processes described above. According to the Secretaría Regional Ministerial de Agricultura (Regional Minister's Office of Agriculture), the Biobío Region has a total of 953.000 hectares $(2.360,000$ acres $)$ of forestry plantations, and $76 \%$ of national forestry exports, especially cellulose, paper and chipboards (http://biobio.minagri.gob.cl/nuestra-region/ vision-de-la-region/).

The forestry-paper complex has established several pressures over peasant economies. Forestry plantations directly displace producers through land acquisitions, struggles for water resources, agrochemical contamination and, also, the permanent danger of forest fires, which affects adjacent farms. The manufacturing industry of paper and cardboard -settled mainly in rural areas- has been characterized by a high use of water and high atmospheric pollution (sulfur and chlorinated organic compounds) and massive contamination of water with industrial waste (INDH, 2012), undermining directly the productive capacities of adjacent rural producers.

This pressure on peasant economy increases with the political ideology of the government, which encourages peasants to respond to "the challenge of the market". This practice hides familiar and community dimensions of peasant agriculture, defining them as individual producers oriented to the market and imposing analytic and normative categories of capitalocentric and developmentalist discourses to peasant economies (Gibson-Graham, 2006).

In this context of expansion of agroindustrial economies, only the most isolated areas with less surplus value (coastal drylands and mountain-range) represented "regions of refuge" for peasant economies (Clapp, 1998; Scott, 2011). The Biobío Region-located in the Center-South Chile (36 46'22"S), with a Mediterranean climate and irrigated by numerous rivers and a frontier with the Mapuche territory until $19^{\text {th }}$ century- seems to be one of those "regions of refuge".

Before the implementation of the Agrarian Reform, eventhough the haciendas dominated the Mediterranean zones, the Chillán and Biobío areas developed a zone of smallholding (minifundio) and medium-scale agriculture (Bengoa, 1988). Currently, despite the pressure of agribusinesses and the forestry industry, the Biobío Region concentrates the largest number of small properties in Chile. In fact, according the last Censo Agro- 
pecuario (Farm Census), the Biobío Region holds a 23\% of the use of land with less than 5 hectares (a $48.6 \%$ of the lands of the region) and a 22\% with less than 10 hectares (64.9\% of the region).

\section{Forestry Development in Chile}

The Forestry Industry has experienced an explosive growth, based on intensive monoculture of two exotic species: pines and eucalyptus. By 1973, the export value of the Chilean forestry sector was only US\$ 39.1 million; in 1990 this value reached US\$ 840.4 million; and by 2011 was US $\$ 5.905,9$ million. The factors that contributed of this explosive growth are:

(1) Macroeconomic policies of the government, between 1974 and 1980 important duty fees and non-duty barriers were reduced to stimulate exports.

(2) A number of environmental and social variables that acted as comparative advantages. Firstly, the cool and rainy climate of the region allows species (such as pinus radiata) to reach maturity in 20 years; 15 years faster than in other places. Secondly, the agrarian counter-reform increased substantially the availability of low-cost eroded lands in the coastal drylands. Thirdly, the repression of union movements and labor market flexibility consolidated in the Plan Laboral (Labor Plan) of 1979 during the Military Government, supplied vulnerable and inexpensive workforce. The last two variables (land availability and low-cost workforce) are symptoms of the crisis of familiar agriculture in the context of agroindustrial modernization (Gwynne, 1993).

(3) The political role of Corporación de Productores de Madera, CORMA, (Corporation of Wood Producers), in the generation of a regulatory and favorable framework for forestry development. Although this organization comprises 150 partners, it is hegemonized by two large enterprises Compañía Manufacturera de Papeles y Cartones (CMPC) and Grupo Arauco. CORMA and its members were endangered by the expropriation policy of the Unidad Popular (Allende's administration), and they not only supported the coup d'état of 1973, but also actively lobbied the promotion of favorable legislation for the sector (Gwynne, 1993). As a consequence, in 1974, the reforestation commission of the government, COREF, became CONAF (National Forestry Corporation) and passed to the Ministry of Agriculture to the present, and resulted in the privatization of lands and the enterprises of the State. With this measure, the State left forestry development, reducing its role to a mere promoter.

The same year, the Legislative Decree DL 701 (1974) was issued arguing that forestry activities protect soil from erosion and establishing a subvention - in effect from 1974 to 1998 - up to $75 \%$ of land clearance, planting, enclosure and forestry production management. As a result of this law, the State granted subsidies up to 116 million nominal dollars, founding the plantation of 869,704 ha $(2,149,085$ ac) (Gwynne, 1993). In 
1975, the government passed a decree authorizing the exportation of forestry products regardless of aggregated value and the amount of elaboration in Chile. This opened the exportation of logs and timber products that before had been forbidden (Gwynne, 1993).

After 1998 -in democracy and under a center-left administration- the law 19.561 (1998) was issued and modified DL 701, extending its validity to 2011, and special benefits were given to small and medium owners, subsidizing up to $90 \%$ of the plantation cost of the first 15 he $(37 \mathrm{ac})$.

By 2008, different actors of the forestry sector assessed that planted forests to the date were used to the limit of the economic offer. In addition, there would have been some difficulties to acquire new lands, for example, the small size of lands and the restrictions of the Indigenous Law 19.253, which restrains non-indigenous people to acquire community lands. This contained the industry expansion and created the need for incorporating familiar peasant agriculture to the forestry business (Leyton, 2009). This drew the attention to the Biobío Region, where a dynamic forestry industry and a region of refuge for peasant agriculture coexist. In fact, the "Proposal for the Development of a Forestry National Plan", presented in 2008 by the Colegio de Ingenieros Forestales de Chile states the need of:

"properly incorporating peasants (AFC) to the forestry business, especially, to the use of resources. The proposal of development of AFC (...) states local and regional integration of forestry peasant producers inside production chains (...) promoting forestation with forestry plantations (using multipurpose species), in supplying areas of manufacturing industries of wood and non-wood products (CIFAG, 2008: 39)

In this context, the Law 19.561 (1998), which modified the DL 701, is particularly important. DL 701 excluded small land owners, since the benefit required: (1) to pay the expenses to recover later $75 \%$ of the cost and (2) to keep accounts of incomes and expenditures. Both requirements were removed by the Law 19.561. The new law considers a bridging credit to finance the forestry plantation and, also, establishes that small forestry owners will always pay taxes according to presumed income; therefore, they do not have to keep complete accounts (Fiabane, 1998). As a result, between 1998 and 2013, the State granted US $\$ 345$ million for the reforestation of 600,000 he (1.48 million ac).

After the expiration of Law 19.561, the law 20.488 was passed on January $3^{\text {rd }}, 2011$, and modified and extended the period of DL 701 until January $1^{\text {st }}$, 2013. The category of medium forestry owner is created (up to $100 \mathrm{he}, 247 \mathrm{ac}$ ), subject to special benefits and granting special incentives to indigenous communities for land forestation.

The incorporation of peasant agriculture to the forestry sector is related to several processes. Firstly, the objective was to include to the circuit of forestry industry those spaces at the margins or out of their reach. This implied a profound transformation of the agroecological territory, since small lands previously dedicated to small agricultural production (where coexisted wheat plantations, horticulture, small stockbreeding, small fallow lands and small exploitable areas) are now colonized by monoculture forestry.

Secondly, the time transformation of peasant economies is another significant process. Peasant economies are organized according to agriculture and family vital cycles, and now forestry plantations reorganize this temporality. Forestry plantations do not ge- 
nerate short-term profits or annual incomes. This forces small forestry owners to look for income mechanisms, mainly inside forestry corporations. The long-term growth of forests makes difficult to assess the cost-benefit; in fact, the time of production exceeds the time of effective work. This also may be adjusted to family cycles when they decide to plant to ensure the education of their children or their retirement. In this sense, incorporating peasant agriculture to the forestry industry is a mean to externalize the management of time. But also an externalization of all risk.

The period of growth of pines and eucalyptus is a dangerous time, with high vulnerability to plagues, droughts and, especially, fires. Therefore, it is more profitable to the forestry industry to invest in core and sawmill processing than the plantation investment, which can be assigned to peasant production.

Considering the high development of the forestry industry in this "region of refuge" of peasant production, where peasant population is incorporated, it is important to reflect on the nature of this relationship. The impacts of fires represent a particularly important aspect of this reflection.

\section{Nature and Society: a symmetrical bet}

The relationship between nature and society is central to political ecology and theoretically moves between critical realism and constructivist positions (Nightingale, 2002). On the one hand, the first perspective assumes social and environmental areas as existing, separated and mutually contradicting realities. From a Malthusian perspective, the environmental reality is an external limit to socioeconomic growth, for example, O'Connors' Natural Limits. On the other hand, constructivist positions are focused on the linguistic, social and politic process of production of nature. From this perspective, we find the social construction of nature (Eder, 1996) and the production of social nature (Castree and Braun, 2001).

However, these positions are deeply anthropocentric, since the focus on the human being obscures the autonomous dynamics of nature, considering it as passive, malleable and vulnerable. Both analytical poles fail to capture the complex relationships between society and nature; therefore, they narrow the understanding of environmental problems (Murdoch, 2001).

In this context, the epistemological works of Bruno Latour offer a mediating bridge considering that natural and social entities are connected by complex interrelationships. (Murdoch, 2001, Castro and Zusman, 2009). The co-constructionist line of Bruno Latour proposes symmetrical descriptions of how human and non-human actors (nature, technology and material artifacts) interact, form networks, assemblages and heterogeneous associations that act collectively and form our world (Callon and Law, 1997). This implies to overcome reductionisms that consider material conditions or human beings as the only source of change or social stability, since these relationships are frequently complex and contingent. Here, action is considered as the product of the complex mobility of a network of actors and actants: an actor-network (Latour, 2006). Each actor is a collective (and rhizomatic) performance where the multiplicity 
of human and non-human elements are translated and stabilized (Callon and Law, 1997).

For the symmetrical analysis of our particular case study, it is important to mention that the fire as an actant was considered as a Latourean quasi-object (social and natural); a constructed reality, in the terms of Smith (2007); and a created ecosystem, according to Harvey (1996). The substantial injection of capital; State subsidies; demand of paper, pines and eucalyptus; and paper corporations, have created an ecology highly vulnerable to fire. The massive cult to exotic species, out of their context, subordinated to a temporal rationale and the accumulation purposes of capital corporations, produce a socio-natural assemblage with a distinctive ecology and wide territorial and temporal coverage. These particular ecologies are actants, since they have a materiality that transcends social control -as dramatically shown by forest fires-and have non-anticipated effects in the nature-capital relationship.

Latour, in Politics of Nature (2004), clalls for a political ecology transcending dualities between social and natural sciences to account for collective and heterogeneous assemblages, which are the socio-natural processes. In the field of politics and, occasionally, in social sciences, modern science distinguishes between the discussion about the facts -objective and external- and values. However, this division can be dangerous since it ignores the social construction of facts and nature, and also generates a political discussion ignoring the autonomy of the processes of the natural world. Talking about political ecology, according to Latour, must reveal the assemblages, the symmetric human and non-human collectives where social relationships are constructed. In terms of politics, this implies the politicization of objects and nature, subjects come to the political world not only as linguistic individuals, but also as members of collective human and non-human associations, that transcend subject-object dichotomies.

To politically talk about assemblages in rural Chilean context requires to problematize the role of capitalism. However, using hyper-general categories such as "capitalism" is a contradiction to the Latourean principles of symmetrical sociology. For this reason, this concept will be used in the sense of Castree (2002) as a contingent stabilization of actors and processes that maintain a certain historical regularity in the territory. From Swyngedow (1999) it is possible to say that forestry development in Chile has been a geographical project, which covers an intense transformation of landscape (nature-society re-assemblage) and expresses a progression of familiar agriculture, monoculture establishment, reduction of hydric resources, etc.

Further, as stated by Castree (2002), the circulation of capital -in this case of the forestry accumulation process- is embedded in an ecology, co-constructed in this case. However, regardless of its participation in the process of accumulation, nature is invisible, since this process is only organized from the category of work. According to Swyngedow, human, natural, material and technological processes that interact in the creation of the socio-natural hybrid of forestry plantations suffer from considerable tensions and conflicts. These processes are not completely subsumed to the control of capital (or human control in general), but rather the metabolism of nature -including produced nature- transcends the control that human actors establish. To produce a new 
nature does not mean to be capable of controlling this new nature. This conserves its own agency, an ecology where fire and its consequences are omnipresent. The category of work aspires to create objects - which are assumed under control-; however, these are quasi-objects that escape from human control and have dramatic consequences for the other actors of the network.

In this way, the source of the nature-capital contradiction is not an external limit established by nature, but the irreducible properties of a socio-natural network assembled in the sphere of operation of capital. For example, forcing species -such as pines and eucalyptus- out of their ecosystemic context (considering their value as goods), they are more vulnerable to fires and alter pre-existent agroecologies. In this sense, it is observed an acceleration of the contrast between the times of accumulation of capital (linear and short-term) and the cycle times of survival and family and nature reproduction (non-linear and multiple).

All in all, capitalism as a coordination of actors and actions is central in the configuration of a territory where the land has been concentrated and monoculture dominates the landscape. Forestry corporations, supported by exceptionally favorable regulations, are the central actors of the spatial configuration of the region. However, in this context, natural entities are active in the process of circulation, variable and contingent to each case. Capital before being anti-ecological is a creative destroyer (Smith, 2010); then, this draws into question what -rights and wrongs- and for whom are they being created. Between the created rights and wrongs, we find the dispossession (Harvey, 2003) of peasant economies; in other words, the transformation of traditional peasant economies based on subsistence into economies based on salary and commercial agriculture.

\section{Methodological approach}

The recurrence of forest fires represents an explicit material symbol of the socio-environmental instability of this assemblage, forestry plantations. This fire in particular -because of the proximity to urban areas, the tragic death of forest firefighters and the high economic cost to peasant economies-represented a dramatic political symbol of the phenomenon, which raised a large discussion and generated solidarity networks, including the Universidad de Concepción.

At the request of ANAMURI, and with the collaboration of a number of internship students of the Universidad de Concepcion, the damage of 13 localities in the commune of Ranquil and Quillón in the Biobío Region was assessed. To develop the assessment, a first sweep phase was carried out in January in the localities in order to gather the information of all houses and lands affected by fire, contacting people affected in the zone of disaster or the shelters. All adults who lived permanently in the land or the affected homes were considered as valid informants. A total of 208 surveys were gathered in this sweep, which did not included random selection techniques (impossible at the moment of the catastrophe), but responded to a census proxy of affected people. The surveys included closed and opened-ended questions about the following topics: 
1. Material damage in residential and productive infrastructure by fire.

2. Personal, physical and psychological damage of the disaster.

3. Perception of causes and responsibilities.

4. Types of received assistance and local organization management.

Topics 1 and 4 were closed-ended questions, and topic 2 and 3 were elicited through open-ended questions. The responses were later re-coded by themes.

After the first sweep, 12 in-depth interviews were carried out with neighborhood leaders and 5 social cartographies were mapped with people considered relevant inside their own communities. The interviews were focused on the history of local landscape, its economic evolution and the relationship between forestry industry and peasant life. The result of cartographies were collectively constructed maps of the lived space. In particular, participants were asked to draw their living area, identifying the social use of space, meanings, elements of their history and possible futures, with especial attention paid to territorial controversies. The exchanges during the map construction were recorded. The data of in-depth interviews and the cartographic exercises was treated with content analysis techniques. Later, some students who participated in the data gathering developed thesis with similar approaches in the territory, gathering -through ethnographic methodologies-perceptions and strategies of local inhabitants relating to the forestry industry. Finally, a press analysis was developed about the treatment of the event by the media.

\section{The difficult cohabitation in the forestry-paper complex}

Cohabitation with the forestry-paper complex is difficult, since this complex endangers the viability of peasant economies, which are affected by the plantation of exotic species and the operation of cellulose corporations. The most direct influence of forestry plantations on agriculture is the high use of water sources - especially groundwater- which competes with peasant communities for its use. Although scientific literature is contentious about assessing the effective use of water resources and the modification of water properties of the soil by the forestry industry (Oyarzún et al., 2011), the subjective experience of peasant communities is that intensive forestry -near to water courses-would have contributed to dry run-offs, wells and estuaries.

"The problem is that the plantations are too close to water sources, so the pines absorb all the water. They don't act in good faith, because the law says that they must plant at 30 meters [100 ft] of native forests, so the wells wouldn't dry, but they don't respect this and we have been struggling here with this problem, all the people in the area has a fight with Mininco [forestry corporation]".

This damage to water resources is exacerbated by liquid industrial waste, which the paper industry regularly disposes in open water courses, altering the variety of uses that the peasant world gives to estuaries and rivers. 


\begin{abstract}
"Now it's impossible, you won't go to the river, because we are concerned about the contamination, and it may have something ... The level is lower, it has less water and it's dirty. Some days the water is very dirty and others it has scum"

"In the past you could swim, fish, but now nobody is willing to go to the river". (Thesis Interviews, Durán, 2014)
\end{abstract}

We have to consider also the emissions of sulfur and chlorinated organic compounds. Peasant communities state that both processes are harmful to health and farming:

\begin{abstract}
"The constant smell and more importantly acid rain are realities. In the morning we get up and see clouds that doesn't get you wet, but are attached to plants".

"In the past, there were much more vineyards and now we don't have any... the fields are poorer and after the construction of the plant [paper] this commune became one of the poorest in the region". (Thesis Interviews, Durán, 2014).
\end{abstract}

Before the fire of 2012 -presented in this article- there were at least two events associated to the forestry complex with considerable consequences to the peasant population of the region.

The first was a massive leak of "Black Liquor" - a waste product of cellulose production containing resin acids and heavy metals - in the Nueva Aldea plant, as a consequence of the megathrust earthquake that stroke the zone on February $27^{\text {th }}, 2010$. The waste spilled directly over adjacent lands causing complete loss of harvest and compelling the enterprise to pay full compensations.

The second, on September 2011, was a spillage of industrial liquid residues without treatment to the Vilumanque estuary, branch of the Itata River (one of the most important basins of the region). These events are not the exception, since similar incidents were registered in other zones of the country -for example, the spillage in the Cruces River in Valdivia (Sepúlveda and Bettati, 2005, Selva, 2005).

\title{
The fire and the aftermath
}

The statistics of the National Forestry Corporation, CONAF (2011), estimate that between 1984 and 2011 more than 1.4 million he ( 3.6 million ac) were damaged by forest fires in the country, in 152,284 events. An historical average of 5,640 fires and 53,836 ha. $(133,000 \mathrm{ac})$ per year. The Biobío Region was the most affected with an average of 1,973 fires per year (1977-2011) and an annual loss of 11,380 ha. (28,000 ac). In perspective, the dramatic - and high profile - fire of 2011 doubled the annual average of the region. This situation was largely realized by the neighbors of forestry plantations, who stated that "as long as forestry industries are here, the fires will continue...".

Despite of the recurrent history of fires, the event of 2012 had particular dramatic consequences. According to the data gathered in the 208 surveyed families, rural proper- 
ties -generally small (average $22.3 \mathrm{ha}, 55 \mathrm{ac}$ )- were almost completely damaged and an average of $86.8 \%$ of property surfaces was consumed. The percentage in farming areas is more dramatic with a $97 \%$ loss. These numbers reflect the incapacity of private efforts to extinguish the fire, the weak institutionality of the State to control fire outbreaks and the almost non-existent institutionality of the private sector. In fact, forestry corporations did not have specialized forest firefighters and the firefighters of CONAF could only contain the fire through fire lanes, which limited the propagation, but did not protect the areas enclosed by flames.

$40 \%$ of affected families lost their houses. Some people could save part of their lands through private means of control, building fire lanes around the houses and scarifying the rest of the property. Storehouses and stables could not be protected in the same scale and $57 \%$ suffered complete losses.

The most damaged part of the population were households headed by women. These houses -without adult men- probably preferred human evacuation rather than saving the property. This substantial gender difference draws into question the lack of community and public networks to support these homes, which reveals once again the privatization of rescue actions, leaving this task to the action of families.

\section{Table 1. Percentage of total damage of infrastructure according to the sex of household head.}

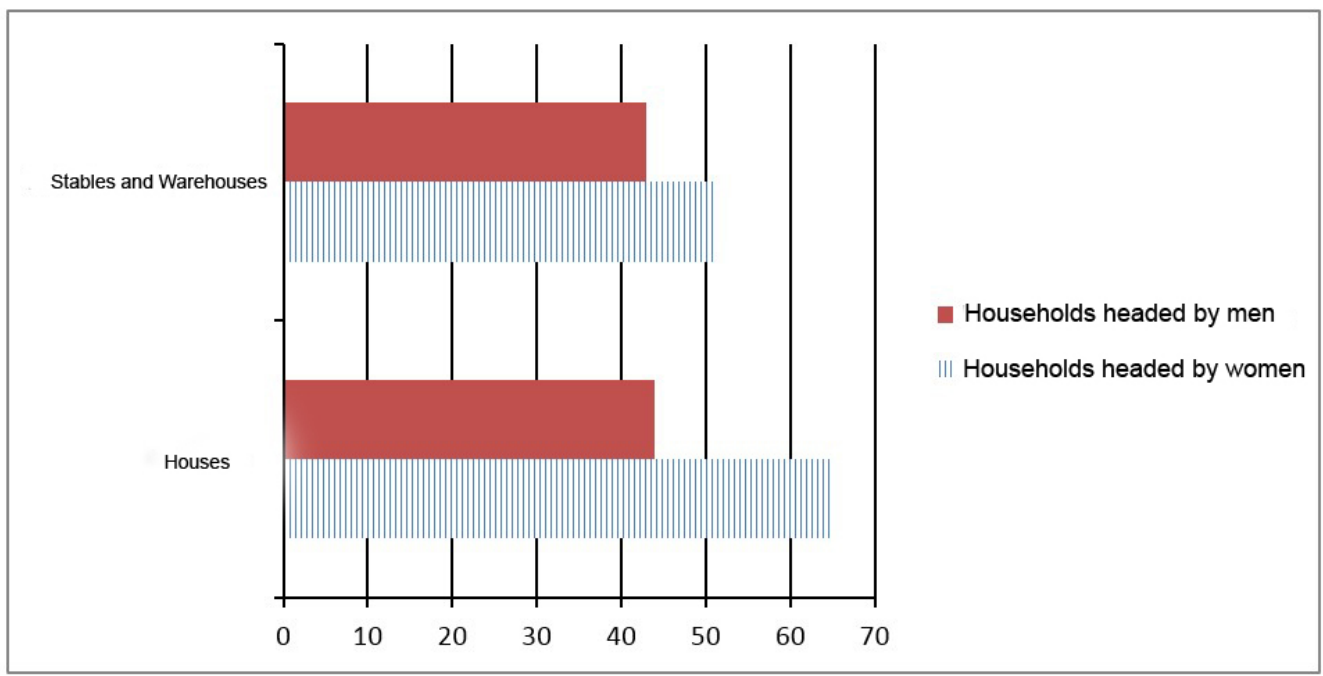

The damage to water courses and infrastructure is particularly interesting in socio-environmental terms. As previously stated, the water management of forestry industry has been historically criticized, since it modifies hydrological properties of soil, regardless of the regulatory dispositions of plantations near water courses.

Now, there is a perception that these dispositions have been violated and water courses have been considerably reduced. In fact, the survey of farmers revealed that the fire caused minor damages to water courses and, ironically, $50 \%$ of the interviewees 
stated that after the fire water courses have increased their level. The perceived cause of this level recovery is the absence of pines and eucalyptus. Whereas water courses were slightly damaged, domestic infrastructure for water management (watering and supplying) suffered severe consequences with a total damage of $85 \%$ of canals, pumps and hoses.

Finally, the assessment showed that almost all fruit and timber trees, vineyards and farms disappeared. Only animals - especially with high mobility- could be rescued: many interviewees stated that "the animals escaped without human intervention". Only one or two months before harvest, these losses represented an extremely high cost to peasant economies of annual cycle, already impoverished.

Table 2. Damages

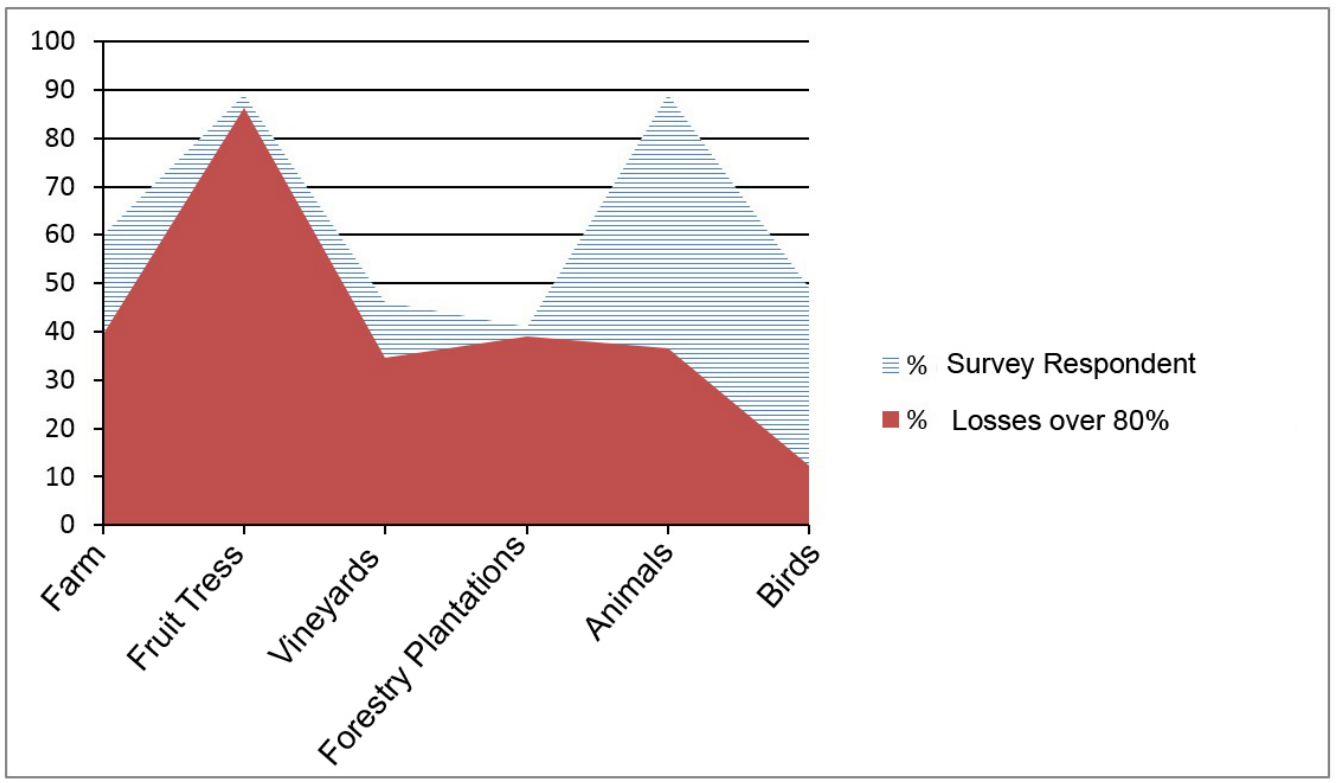

In terms of casualties, the fire caused the death of two residents and seven forest firefighters. All interviewees stated that they or their family members suffered from psychological aftereffects: fear of manipulating fire (even stoves), anxiety, panic attacks, among others. In the same way, $77 \%$ stated that they or their family members suffered from physical aftereffects: mainly burns of different degrees and respiratory conditions.

In addition to the recurrence of these events, the results showed that the damage of forest fires to peasant communities and economies are excessively high and represent serious restrictions for the development of independent projects of accumulation. These restrictions are not only the permanent struggle for water use or agrochemicals abuses, but also the complete destruction related to the constant and latent danger of uncontrollable forest fires. To this matter, it is particularly dramatic the fact that $71 \%$ of the interviewees considered that this fire was intentional and even $22 \%$ blamed the forestry corporation: 
"Well, people say that the other fires spots were intentional and gave them the chance to start more fires to recover all dead forests that they had, because from this point all forests were infected". (Social Cartography).

In the same way, $22 \%$ of interviewees claimed that the magnitude of the fire is a consequence of the absence of effective actions of prevention (21,51\%). This includes the maintenance of fire lanes; clearance of road, fields and property; restriction of camping areas; incineration control, among others. The failure of forestry industry to comply with these measures represents a violation to current regulations. In the case of small forestry owners - peasant families that plant trees in their lands through subsidies- these measures are rarely implemented.

In the field work, we observed the lack of fire lanes, so that houses and private lands are separated from forestry plantations only by secondary roads. This is aggravated in the case of small forestry owners, who plant trees very close to their houses to cover as much space as possible.

This proximity of forestry plantations and communities has arises a feeling of enclosure.

\footnotetext{
"It's bad, because forest companies are at the front yard, because we are here at two hundred meters [600 ft] of a forestry corporation. From here to the hill over there. But from here to the other side at three hundred meters [950 ft] there is another forestry corporation. So everything is lost" (Social Cartography)

"We are few rescuing small areas of farm. Forestry corporations have cornered and enclosed the others, they have to sell their lands because, and what can you do? (In-depth interview to a neighborhood leader).
}

This situation has a direct and considerable impact on the value of land.

\begin{abstract}
"Yes, pines do that, everyone is surrounded by pines up there, because forestry corporations have destroyed and cornered farms, so they must sell their lands at a very cheap price, here an hectare can cost 12,000,0000 pesos and in Cerro Negro which is part of the forestry complex an hectare costs 300,000 pesos" (Thesis InterviewCarrasco, 2013).
\end{abstract}

In this context, the relationship with the forestry industry is influenced not by exclusion -which seems to be resolved with the law 19.561- but through the inclusion conditions and the relationship between the industrial assemblage and peasant economies; especially, in relation to a dispositive such as the (non)existence of fire contention and other measures to secure and compensate farm owners externally affected by fires.

The question here is who assumes these compensatory measures and how to address the problem of the fragilities of forestry assemblages and its externalities. A year from the disaster, forestry corporations have not assumed any economic or legal responsibility 
about their consequences. In fact, these costs have been discursively and materially privatized. There have not been specific compensatory measures, which fell into the hands of the State.

Chilean legislation does not consider the externality figure in forest fires: the corporations are not legally responsible for the damage that fires in their lands cause to third parties. They are only accountable for the violations to the Forest Law (for example, absence of fire lanes), which can involve penalty payments, but does not reach the high economic costs of possible fires.

If peasant communities have an opinion and judge the responsibilities of the forest-paper complex of recurrent fires, what is the judgment of the hegemonic political discourse? From the beginning, government actors made public statements oriented to move the cause of the disaster from socio-natural characteristics of a productive model hardly regulated to a private action of criminal and irresponsible individuals. Particularly, during the fire, the Minister of Interior blamed -without proof-terrorist actions of Mapuche people (El Comercio, 2012). Only 15 days after the fire, the president's office presented a project of Law to reinforce penalties to people responsible for forest fires. This project -materialized in the Law 20.653 (2013) - reinforces penalties to negligent or criminal behaviors that directly cause fires, but do not significantly modify the regulations and penalities to the forestry sector (Biblioteca del Congreso Nacional de Chile, 2013).

In the same way, as part of the shift of responsibility of the fire, a year after the event a presumed suspect was arrested. The syndicated was a forestry worker who had been dismissed, who would have started the fire as a revenge against the corporation (Guzman, 2013). This event finished the privatization of the responsibility of the fire, hiding the question about the consequences of an unregulated productive model which permanently generates externalities.

Forestry corporations have not assumed the reconstruction costs of the severely damaged peasant economies. During 2012, all economic support received came from public funds. The State sent through INDAP (Institute for Farming Development) bonds for the acquisition of supplies and reconstruction of productive systems to 550 small farmers for a total of $\$ 335,800,000$ (US $\$ 671,600$ ); $\$ 214,000,000$ (US\$ $428,000)$ to recover investment to 85 medium farmers (Reyes, 2012); $\$ 77,000,000$ (US\$ 154,000 ) to recover watering systems, $\$ 500,000,000$ (US $\$ 1,000,000$ ) to the replacement of infrastructure (fences and warehouses) and $\$ 2,200,000$ (US $\$ 4,400$ ) to the program for entrepreneurship recovery of small producers (Programa de Reemprendimiento de Pequeños Productores). The National Forestry Corporation will reforest 1,000 he $(2,400 \mathrm{ac})$ in two years, and will provide technical assistance to 300 small forestry owners.

In addition, the State has spent on the reconstruction of damaged roads (Taurán, 2012); rodent control, and natural patrimony restoration of the Cayumanque ecosystem (Cisterna, 2012). This may be consider as a new and massive form of indirect subsidy to forestry activities; therefore, the profits of this industry are private, but the costs are firstly externalized to peasant families and then socialized through State contributions. 


\section{Final thoughts: the assemblage fragility and agriculture as resistance}

For Latour, political ecology implies the politicization of objects and nature into collective human and non-human associations that transcend subject-object dichotomies. Therefore, the challenge is to politically discuss this socio-natural assemblage, the forestry model, which has not only been established in the space of traditional peasant economies, but has also actively sought their agencement as small forestry producers. This opens an indirect access to the lands, which would be difficult to acquire; facilitates the externalization of a part of the working time -particularly the period with less surplus value-; and also externalizes 20 years of risks -pests, droughts and fires- related to the growth of plantations.

However, peasant communities in the Biobío Region have a resilient history. They have occupied the region of refuge and have adapted for a long time to the adverse conditions and the pressures of dominant economies. Now, facing the omnipresent forestry corporations, they have developed new forms of adaptation, negotiation and, as we observe, resilience. For this reason, considering the massive and inevitable presence of the forestry industry, their actions are strategic and indirect. Despite the apprehensions about the impact of forestry production in their own communities, many families choose not only to work in the industry, but also to plant pines and eucalyptus in their own lands. They act as small forest owners in articulation to the paper industry and receive generous subsidies for forestation.

As a result, forestry assemblage (highly socio-ecologically fragile) is even more unstable and becomes an unmanageable quasi-object. If forestry corporations barely follow the regulations about fire lanes, number of forest firefighters, and other fire prevention measures; these requirements are impossible for small forestry owners.

The distribution of the costs of this instability is certainly inadequate, and as presented thoroughly in this article, in the case of disaster, the damages are mostly assumed by peasant economies and contained from public spending. There are no legal obligations compelling the industry to face these externalities.

The forestry assemblage approaches peasant families with the politics of wishes. The families face the dilemma of rejecting forestry industry in their lands or looking for an alternative of inclusion to this model through employment or becoming small forest owners. In their search for survival the only alternative seems to be to wish for what they reject. But is it?

In this context, I want to go back to the symbolic and political possibilities of the work of ANAMURI, an associated organization to this study. The ANAMURI meeting -where a preliminary version of this article was presented-was closed with a trefkintu, a rite which helped to transform the mourning for the fire into an affirmation of hope. A trefkintu is a ritual -tracing back to Mapuche exchanges-consisting in exchanging small amounts of seeds to their propagation in other vegetable gardens. The recovery of this traditional practice of propagation of seeds responds to the development of a decentralized project of biodiversity management carried out by a local NGO. It has reached deep effects in peasant communities as a performative rite; in fact, many social and political activities begin or end with a trefkintu. 
The trefkintu, as a collective association of peasants, seeds, land and knowledge, represents a space of politicization of subjects and objects, where hope and resilience is constructed. The political construction of alternatives to the model of forestry accumulation does not seem to be related to the participation -more or less favorable-inside this socio-natural network; but through the economic and political affirmation of alternative networks established in the revalorization of peasant economies, as shown in the performance of the "requestors" of this study, ANAMURI.

This performance follows a double transformation of peasant politics. Firstly, there is a reorientation from negotiation and opposition policies with the -agricultural and forestry-industry to a policy seeking to recover peasant identities. Secondly, a transformation from the demands for lands to a wider claim involving the complexity of the territory appropriation, which does not exclusively conceive space as plain land, but also as nature, people, water and seeds. In such context, and facing the progressive agroindustrial monopoly of seed production, to recover the control of a wide genetic pool of seeds represents a major objective for the peasant world.

Examining the process of forestry accumulation, only the continuity of peasant territorial occupation and the continuity of agricultural practices are active forms of resistance to the forestry assemblage, generating an alternative assemblage which politicizes and respects the interest of the different actors: peasants, land, nature, seeds, and biodiversity. Resisting dispossession and claiming the right to the exercise of agriculture, implies a redefinition of the options and criteria of the economic rationale. Their political opposition is based on a renounce -even a rejection- of the utility maximization standard, which is replaced by a social and ecological criteria for the subsistence and reproduction of life. In this sense, the peasant agroecological project is a post-capitalist performance, rather than a stronghold outside capitalism (Gibson-Graham, 2006). After experiencing processes of displacement and dispossession, related to the participation in the socio-natural assemblage of capitalist production, peasants react to them with the wilful affirmation of subsistence and a wider reproduction of life as a central economic value.

This option is not a localist choice and is based on the creation of an alter-transnationalized rural space, as evidenced on the living international relationships between peasant leaders. In parallel to the presence of corporations and agribusinesses, different forms of peasant organization emerge connecting organized producers and global organizations. Through the participation in Vía Campesina, local initiatives and problems, affecting different places, are connected. The struggle for the land and water, the rescue of seeds and biodiversity, alimentary sovereignty, are relevant arguments at global and local scales, which connect particular peasant lives and struggles with the global movement of counterproposals to capitalist globalization (McMichael, 2008). 


\section{Bibliography}

Bengoa, José. 1988. El poder y la Subordinación. Ediciones Sur. Santiago de Chile.

Biblioteca del Congreso Nacional de Chile, 2013. Historia de la Ley $N^{\circ} 20.653$. Aumenta las Sanciones a Responsables de Incendios Forestales. Biblioteca del Congreso Nacional de Chile.

Callon, Michael y Law, J. 1997. After the Individual in Society: Lessons on Collectivity from Science, Technology and Society. Canadian Journal of Sociology 22 (2): 165-182.

Castree, Noel and Braun, B. 2001. Social Nature: Theory, Practice and Politics. Oxfordand New York: Blackwell, 2001.

Castree, Noel. 2002. False Antitheses: Marxism, Nature and Actor-Networks. Antipode 34 (1) $111-146$.

Castro, Hortensia y Zusman P. 2009. Naturaleza y cultura: ¿dualismo o hibridación?. Una exploración por los estudios sobre riesgo y paisaje desde la Geografía. Investigaciones Geográficas 70: 135-153.

Chonchol, Jaques. 2006. Reforma y Contrareforema Agraria en Chile". Consulta de Expertos de Reforma Agraria en América Latina, Oficina Regional de la FAO para América Latina y el Caribe. Santiago, Chile.

CIFAG. 2008. Propuesta para el Desarrollo de una Política Nacional Forestal. Colegio de Ingenieros Forestales - FAO. http://www.cifag.cl/_file/file_161_politica\%20forestal\%20 editada\%20final_c.pdf

Clapp, R.A. 1998. Regions of Refugee and the Agrarian Question. Peasant Agriculture and the Plantation of Forestry in the Chilean Araucanía. World Development 26 (4) 571-589.

Eder, Klaus. 1996. The social construction of nature: A sociology of ecological enlightenment. London: Sage.

Echenique, Jorge y N. Rolando. 1989. La pequeña agricultura, Santiago de Chile, Agraria.

El Comercio. 2012. Gobierno chileno cree que radicales mapuches están detrás de incendios. Su ministro del Interior, Rodrigo Hinzpeter, aseguró que siniestros son intencionales y coordinados (6.01.2012). http://elcomercio.pe/mundo/1357514/noticiagobierno-chileno-cree-que-mapuches-estan-detras-incendios

Fiabane, Claudio. 1998. Fomento Forestal. Decreto Ley 701 de 1974 y Ley 19.561. Temporada Agrícola (ODEPA) 11: 1 -16. http://www.odepa.gob.cl/odepaweb/serviciosinformacion/tempo/t11-e2.pdf

Gibson-Graham, J-K. 2006. The End of Capitalism (as we knew it). A Feminist Critique of Political Economy. University of Minnesota Press. Minneapolis.

Gomez, Sergio y Echenique, Jorge. 1988. La Agricultura Chilena: Las dos caras de la Modernización. FLACSO-Agraria. Santiago de Chile.

Gwynne, Robert. 1993. Non-traditional export growth and economic development: the Chilean forestry sector since 1974. Bulletin of Latin American Research 12, 147-169. 
Gwynne, Robert y Kay, Cristobal. 1997. Agrarian Change and Democratic Transition. An Introduction. Latin American Review 16 (1): 3- I0.

Guzman, Gerson. 2012. Aseguran que hay pruebas para responsabilizar a detenido por gigantesco incendio de Quillón en 2012 (19.01.2013). Radio Bio Bio. http://www. biobiochile.cl/2013/01/19/aseguran-que-hay-pruebas-para-responsabilizar-a-detenidopor-gigantesco-incendio-de-quillon-en-2012.shtml

Harvey, David. 2003. The New Imperialism. Oxford, New York: Oxford University Press. INDH. 2012. Mapa de Conflictos Socioambientales en Chile. Santiago de Chile: Instituto Nacional de Derechos Humanos.

Kay, Cristobal. 2002. Chile's Neoliberal Agrarian Transformation and the Peasantry. Journal of Agrarian Change 2 (4): 464-501.

Latour, Bruno. 2004. Politics of Nature: How to Bring the Sciences into Democracy. Hardward University Press.

Latour, Bruno. 2006. Reasembling the Social. An Introduction to Actor Network Theory. USA: Oxford University Press.

Latour, B. 2007. Nunca fuimos Modernos: ensayo de antropología simétrica. Mexico D.F: Siglo XXI

Leyton, José Ignacio. 2009. Tenencia Forestal en Chile. FAO. http://www.fao.org/ forestry/54367/es/chl/

McMichael, P. 2008. Peasants Make Their Own History, But Not Just as They Please. Journal of Agrarian Change 8 (2-3): 205-228.

Ministerio de Agricultura. 2007. Censo Agropecuario 2006 - 2007. Ministerio de Agricultura. Santiago de Chile.

Murdoch, Jonathan. 2001. Ecologising Sociology: Actor-Network Theory, Co-construction and the Problem of Human Exemptionalism. Sociology 35 (1): 111-133.

Nightingale, Andrea. Can Social Theory Adequately Address Nature-Society Issues? Do political ecology and science studies in Geography incorporate ecological change?. Institute of Geography Online Paper Series: GEO-027. Third International Critical Geography Conference Békéscsaba, Hungary, June 25-30, 2002

Ortiz, María Selva Ortiz et. al. 2005. Entre el desierto verde y el país productivo: el modelo forestal en Uruguay y el Cono Sur. Montevideo: Casa Bertolt Brecht.

Oyarzún, Carlos et al. 2011. Propiedades hidrológicas del suelo y exportación de sedimentos en dos microcuencas de la Cordillera de la Costa en el sur de Chile con diferente cobertura vegetal. Bosque 32(1): 10-19.

Reyes, Carolina. 2012. Avanza reconstrucción productiva de agricultores afectados por incendios forestales en Quillón (30.05.2012). Radio Bio Bio. http://www.biobiochile. $\mathrm{cl} / 2012 / 05 / 30 /$ avanza-reconstruccion-productiva-de-agricultores-afectados-porincendios-forestales-en-quillon.shtml 
Reyes, Carolina. 2012. Ministro Mayol destacó avance en entrega de recursos a afectados por incendios forestales en Quillón (08.07. 2012). Radio Bio Bio. http://www.biobiochile. cl/2012/07/08/ministro-mayol-destaca-avance-en-entrega-de-recursos-a-afectados-porincendios-forestales-en-quillon.shtml

Salazar, Gabriel. 2003. Historia de la Acumulación Capitalista en Chile

Scott, James. 2011. The art of not being governed. An anarchist history of South East Asia. Yale University Press.

Smith, Neil. 2007. Nature as Accumulation Strategy. Socialist Register 43: 19 - 41.

Swyngedouw, Erik (1999): Modernity and Hybridity: Nature, Regeneracionismo, and the Production of theSpanish Waterscape, 1890-1930, Annals of the Association of American Geographers, 89:3, 443-465

Tauran, Erasmo. 2012. Quillón: Vialidad compromete trabajos para evitar derrumbes por lluvias en zona del mega incendio (24.05.2012). Radio Bio Bio. http://www.biobiochile. cl/2012/05/24/quillon-vialidad-compromete-trabajos-para-evitar-derrumbes-por-lluviasen-zona-del-mega-incendio.shtml

Submitted on: 21/06/2013

Accepted on: 06/10/2014

http://dx.doi.org/10.1590/1809-4422ASOC720V1812015esp 



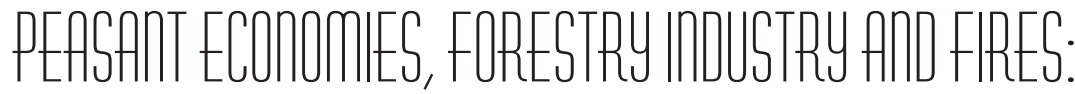

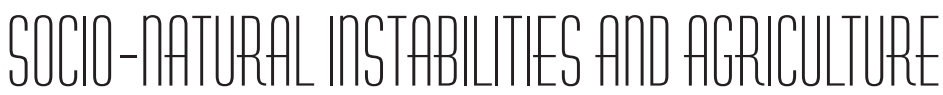 ASAMEEAR OF RESISTARCE
}

\section{BEATRIZ EUGENIA CID AGUAYO}

Resumen: La recurrencia de incendios en los monocultivos forestales chilenos plantea preguntas acerca de la estabilidad socionatural de las economías monoexportadoras. Este artículo problematiza la relación territorial entre la industria forestal -fuertemente subsidiada- y la agricultura campesina -históricamente marginalizada- mostrando las dificultades para la convivencia entre ambas, y para la estabilización de un ensamblaje socionatural que respete e incluya las necesidades de todos sus actores humanos y no humanos.

Palabras Claves: Industria forestal, economía campesina, incendios forestales, socionaturaleza.

\begin{abstract}
The recurrence of fires in Chilean monoculture forestry raises a number of questions about the socio-natural stability of mono-exporting economies. This article problematizes the territorial relationship between forestry industry -heavily subsidized-and peasant agriculture -historically marginalized-, revealing coexistence and stabilization difficulties and problems to reach a socio-natural assemblage respecting and including the needs of human and non-human actors.
\end{abstract}

Keywords: Forestry Industry, Peasant Economy, Forest Fires, Socio-Nature.

A recorrência de incêndios florestais levanta questões sobre a estabilidade sócio-natural das economias mono exportadora. Este artigo questiona a relação territorial entre a indústria florestal -fortemente subsidiada- e a agricultura camponesa -historicamente marginalizada- mostrando as dificuldades da convivência entre as duas, e para a estabilização de uma montagem sócio-natural que respeite e inclua as necessidades de todos seus atores humanos e não humanos. 
Palavras-chave: agricultura camponesa, agricultura camponesa, incêndios florestais, sócionatureza. 